\title{
Chapter 7 \\ The Point of Departure Around 1850: The Turn of the Tide
}

\author{
Harry Lintsen
}

\begin{abstract}
Contents

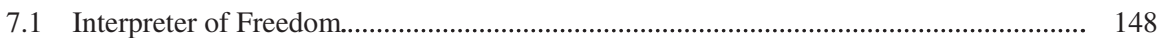

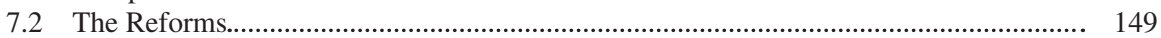

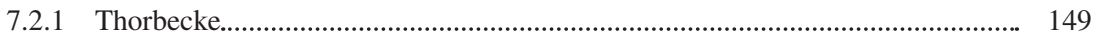

7.2.2 Looking for a New Political Culture...................................................................... 151

7.2.3 The Promise of Technology.................................................................................... 152

7.3 Well-being 'Here and Now': Less Extreme Poverty, 1850 Versus 1910............................ 154

7.4 Well-being 'Later': An Economy Under Steam, 1850 Versus 1910.................................. 156

7.5 Well-being 'Elsewhere': Colonial Profit, 1850 Versus 1910............................................. 158

7.6 Natural Capital and Material Flows, 1850 Versus 1910...................................................... 159

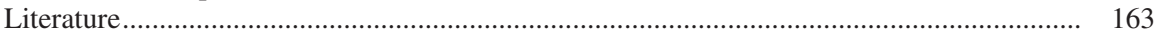

\begin{abstract}
Fundamental changes in politics, economy, technology and 'civil society' took place in the Netherlands in the second half of the nineteenth century. The eminent politician Thorbecke guided the nation through the constitutional reforms around 1850. A new constitution put an end to the power of the king and shifted political power to parliament. The Dutch economy modernised thanks to the liberalisation of trade, an entrepreneurial spirit and other new economic conditions. It was moreover embedded in a new culture that regarded technological innovations almost by definition as social progress. A dynamic 'civil society' was populated by emergent professionals, including engineers and hygienists.

In this chapter, with the help of the well-being monitor, we explore the changes in quality of life 'here and now,' 'later,' and 'elsewhere' for the period 1850-1910. Extreme poverty began to decline significantly, while the burden on natural capital and the natural environment increased. The question is whether this increased burden was problematic and whether it was in fact problematized. We subsequently focus on natural capital, that in this study is seen as the basis of well-being. We make an inventory of some of the important shifts in the production of raw materials and the derivative material flows in the period between 1850 and 1910. This overview isolates the main themes that are worked out in greater detail in the following chapters.
\end{abstract}

This chapter is written by Harry Lintsen with contributions by Fred Lambert, Jan-Pieter Smits and Martijn Anthonissen. 
Keywords Constitution $\cdot$ Liberalisation $\cdot$ Hygienists $\cdot$ Engineers $\cdot$ Monitor $\cdot$ Well-being · Natural capital

\subsection{Interpreter of Freedom}

'While the notables regale themselves with partridges, snipes, hares, ducks etc. etc. that are all non-taxed...', according to the newspaper Interpreter of Freedom in 1840 , '...the working man, as a consumer of meat and bacon, has to pay heavy taxes...bread is also heavily taxed due to the law on milling and this, as is the plan, will also be increased by ten percent...' ${ }^{1}$

The chief editor of the paper was Eillert Meeter of Groningen. ${ }^{2}$ As son of a barber he belonged to the petit bourgeoisie. He had attempted to make a career in the army. His failure in that endeavour he ascribed to his lowly origins. 'The hierarchical chain of society, which has to be climbed by everyone in normal times, is a hindrance to me.' His radical pronouncements, in which he took the side of daylabourers and workers, regularly got him into trouble. In 1841 the High Court condemned him to 4 years in prison and he fled to Paris. This meant the end of the Interpreter of Freedom.

Articles from the inflammatory paper were regularly reported in the national press. These were restless years in the Netherlands. William I had abdicated the throne and had left for Berlin to be married to his Catholic sweetheart - to the accompaniment of a torrent of scorn from the protestant part of the populace. ${ }^{3}$ William II, his son and successor, was beside himself because his silver wedding anniversary was disrupted. The Amsterdam elite was also furious about the financial chaos that William I had left behind. The people were angry and accused the former king of enriching himself and leading a dissolute life with his lady friend. The common man threatened to become the victim of tax increases on food and other daily products that were already heavily taxed and that kept the cost of living high.

The state was all but bankrupt. Successive budget cutbacks by governments had brought little relief. Finally in 1843 the state finances were brought to heel thanks to interventions by the Minister of Finance, Floris van Hall. As a member of Amsterdam's elite he was able to pressure that city's financial and banking establishment into tendering a 'voluntary' loan under favourable conditions. This significantly reduced the interest payments on the national debt.

\footnotetext{
${ }^{1}$ Tolk der Vrijheid', Arnhemsche Courant, 28-11-840.

${ }^{2}$ M.J.F. Robijns, 'Meter, Eillert', Biografisch Woordenboek van het Socialisme en de Arbeidersbeweging in Nederland 3(1988), 132-135. Latest edition: 26-08-2002. http://hdl.handle.net/10622/40FE3915-C651-4BEC-95EF-9E8C802406D4 (externe link)

${ }^{3}$ J. Koch, Koning Willem I, 1772-1843 (Amsterdam 2013), 548.
} 
Nonetheless, this did not suffice to quell societal unrest. Quite the contrary, dissatisfaction increased throughout the 1840s with the potato famine and rising food prices. Political unrest in foreign countries also played into the hand of the political opposition. The time was ripe for radical reforms. The constitutional order would be revised, the tax system revamped and economic life would be regulated. With this, issues of well-being acquired an entirely different context.

\subsection{The Reforms ${ }^{4}$}

\subsubsection{Thorbecke}

In 1848 King William II bowed to popular pressure and appointed a commission to propose a new constitution. The commission commenced its labours on March 17th, under the chairmanship of the lawyer Thorbecke. Ten days later a proposal was ready. Five months after that, parliament saw fit to ratify the new constitution. This provided for direct elections, ministerial responsibility and more parliamentary powers. It was in any case enough to quell disquiet in the country. The political elite, that up to then had turned a pragmatic blind eye to the radical opposition, now abandoned the populist leaders and suppressed an uprising in Amsterdam. ${ }^{5}$

Thorbecke would also preside over the first cabinet to be formed under the new constitution. As Minister of Internal Affairs he successfully shaped a new political landscape. The Provincial Law of 1850 put an end to the ancient estate-based representation in the Provincial Estates. The Law on Municipalities of 1851 put an end to the autonomy of cities and towns that up to then had enjoyed numerous rights, among them the right to veto vital infrastructural projects and thereby strongly influence decision-making by the provinces and the central state. In the newly established framework, the state delegated societal tasks to the provinces and cities. These acquired incomes via a system of earmarked transfers from the public funds. Municipal taxes were formally abolished in 1865. Up to then they had functioned to protect the local markets. Their abolition meant the end of impediments to free market exchange among the cities and between the cities and the countryside. This measure also reduced the cost of living in the cities.

A series of national taxes were also eliminated, including excise taxes on the slaughtering of pigs and sheep (1852), excise taxes on milling (1855) and excise

\footnotetext{
${ }^{4}$ This section is based on: J.L. van Zanden and A. van Riel, Nederland 1780-1914: Staat, instituties en economische ontwikkeling (Amsterdam 2000), 'Chapter 5. Het liberale offensief, 18401870', 209-235.

${ }^{5}$ P. de Rooy, Ons stipje op de waereldkaart: De politieke cultuur van Nederland in de negentiende en twintigste eeuw (Amsterdam 2014), 86-89.
} 
taxes on turf and coal (1865). These had been a burden on the day-to-day existence of particularly the poor and the workers. They also inhibited the modernisation of production. As we shall see, the tax system included numerous regulations to prevent fraud. These measures were the source of considerable bureaucratic red tape. They were aimed in part at small businesses and small-scale production and hindered the coming of the factory and mass-production. The tax reforms put an end to this situation.

These years also witnessed a radical liberalisation of international trade. Under British leadership, a long period of international protectionism was ushered out the back door. The elimination and simplification of various import duties and laws in Great Britain led among other things to the liberalisation of shipping and the import of agricultural produce. Germany eased restrictions on the import of cattle and other products. France abolished measures that strongly protected its industry. The Netherlands participated in the international movement, lowered its import duties to an absolute minimum and put an end to transit and shipping duties at almost all the Rhine and IJssel tolls. The complete freedom of Rhine navigation - blocked for decades by the Dutch state, much to the exasperation of Germany - had finally been achieved.

In the 1840 s and 1850 s government finances had been put in order. National bankruptcy had just been avoided. The interest burden, especially the interest on the national debt, declined as a percentage of state expenditures from more than $60 \%$ in 1840 to less than $40 \%$ in 1860 . This provided an opportunity for the state to lower taxes, assume new duties and initiate new projects. Starting in the 1850 s, river floods were tackled with great zeal. Budgets for education increased significantly after the 1860s. Transport infrastructure was stimulated by the Railway Law (1860). A legal arrangement in 1860 determined that the state would construct the New Waterway (to the harbour of Rotterdam) and private initiative the North Sea Canal (to the harbour of Amsterdam).

The stabilisation of the state finances was possible thanks to the colonial profits from the Cultivation System and the activities of the Dutch Trading Company (NHM). At the outset of the 1840s the so-called credit balance (batig slot) of the colonial Cultivation System that accrued to the Dutch state had decreased to a record low. This was followed by a period of recovery. During the 1840 s, $39 \%$ of the state's tax income came from the colonial credit balance. During the 1850 s that rose to $53 \% .{ }^{6}$ The Dutch East Indies, and in particular Java, paid for a large part of the Dutch state budget. The Dutch railway network, for example, was financed in large part by colonial profits. ${ }^{7}$ This had considerable adverse effects. The creation of more profits led to increased pressure on the Javanese population and the neglect of rice cultiva-

\footnotetext{
${ }^{6}$ Van Zanden and van Riel, Nederland 1780-1914, tabel 5.1, 223.

${ }^{7}$ G. Mom and R. Filarski, Van transport naar mobiliteit: De transportrevolutie [1800-1900] (Zutphen 2008), 216.
} 
tion. In the early 1840 s it had already contributed to the outbreak of a famine. The failure of the rice crop in 1849 and 1850 again caused serious food shortages on Java.

\subsubsection{Looking for a New Political Culture}

The political revolution of the 1840 s released a lot of social energy. According to the prestigious literary journal De Gids, Dutch society had now 'broken for good with that epoch of feebleness and slackness, of lack of ambition... [of a] Netherlands sunken into a deathlike slumber... ${ }^{9}$ De Gids was not referring to William I, who with his inexhaustible energy had initiated countless projects, but to the effete political culture that prevailed during his reign. His autocratic rule had done anything but encourage public debate on social issues. Though both public and politicians were now mobilized, it was still unclear how the new energy should be channelled.

For example, while the constitution guaranteed freedom of religion, the Pope's official declaration of the Netherlands as a church province initiated a shadowy political process..$^{9}$ In 1853, under Thorbecke's leadership, the government took a principled stance and allowed the declaration. King William III, who had no constitutional say in this question, nonetheless used the occasion to support the opposition. 200,000 Netherlanders (out of a total of 3 million!) had been prepared to sign a petition against the 'conspiracy of Rome' and had found in the King a willing ear. In response, the government asked, and was granted, permission to step down, but unrest remained. Due to the acerbic debates and political turbulence in this period, popular trust in political institutions was at a low ebb.

This in itself is hardly surprising, because with the new constitution a number of fundamental questions had to be answered. It was true that parliament now occupied a key position in the new democracy and that the parliamentarian was the chosen representative of a district. But who or what did parliament represent? It was in any case elected by only a small part of the population (initially by some 80,000 male citizens); but even then the question remained whether the parliamentarian had a mandate from his district or whether he was a delegate who represented the interests of the district. Did all the nuances of opinion have to be present in parliament? Or were parliamentarians the advocates of interests? Did something like the 'common interest' exist? A derivative question was who represented the poor and how the interests of the workers, of public health and of public housing were to be represented in parliament.

\footnotetext{
8 'Staatkundige beschouwingen', de Gids 13(1849) II, 487. Cited in: A. van der Woud, Een nieuwe wereld: Het ontstaan van het moderne Nederland (Amsterdam 2006), 15.

${ }^{9}$ De Rooy, Ons stipje op de waereldkaart, 75-77.
} 


\subsubsection{The Promise of Technology}

The new political culture provided new chances for young professionals, including engineers, physicians and agronomists. An ambitious generation of engineers, for example, strained at the leash in their impatience to tackle great works in the interest of the Netherlands and popular well-being. 'A newly born nation,' as they described the situation around $1850 .{ }^{10}$ The plans for the North Sea Canal, the railway network and the reclamation of the Zuiderzee were all ready and would put the Netherlands on the map again. Plans for river improvements could be carried out forthwith and would guarantee a safe delta. For years the engineers had been forced to wait patiently. The sorry state of the public finances prohibited the execution of large projects. One of the few large projects carried out in this period, the reclamation of the Haarlemmermeer, had not brought civil engineers the recognition they had hoped for. ${ }^{11}$ In view of the constitutional reforms, the engineers hoped to acquire a more central social position.

The time also seemed ripe for a greater role for the professional. Technology and science held great promise: '...everything has become possible for our descendants...', wrote the Haarlem instrument maker and aficionado of technological innovation, W.M. Logeman in $1854 .{ }^{12}$ His enthusiasm was rooted in a process that had the entire western world in its grip.

The first World Exposition held in London in 1851 embodied the belief in progress and exhibited its promise to a public of millions that descended on London from far and near. ${ }^{13}$ The main exhibition hall was in itself already an imposing example of technological prowess. It had been built in less than a year from iron and glass and was so transparent that it was justly named the 'Crystal Palace.' It was filled with impressive machines and installations for flour mills, sugar refineries, the machinery industry, breweries and many other branches of industry. The powerful ambiance of mechanical engineering was combined with the more refined radiance of the industrial arts. These exalted crafts exhibited an unbelievable collection of ten thousand luxurious items including cabinets inlaid with mother of pearl, exquisite fabrics, artistic rugs and decorated pianos. Many countries were represented, but it

${ }^{10}$ E. Berkers, Technocraten en bureaucraten: Ontwikkeling van organisatie en personeel van de Rijkswaterstaat, 1848-1930 (Zaltbommel 2002), 37-38.

${ }^{11}$ H.W. Lintsen, R.A. Lombaerts and R. Moerenhout, 'De droogmaking van het Haarlemmermeer: Wind of stoom', in: M.L. ten Horn-van Nispen, H.W. Lintsen and A. J. Veenendaal, Nederlandse ingenieurs en hun kunstwerken: Tweehonderd jaar civiele techniek (Zutphen 1994). The government civil engineers employed by the Rijkswaterstaat had played only a marginal role in the decision-making on the reclamation of the Haarlem Lake, were passed over when it came to leading and executing the project and made no contribution to the British design of the steam engines and pumps for the reclamation (at the time the largest steam engines in the world).

${ }^{12}$ Ln [W.M. Logeman], 'Eeuwigdurende beweging', Praktisch Volks-Almanak 1(1854), 164-167. Cited in: A. van der Woud, Een nieuwe wereld, 15.

${ }^{13}$ M. Bakker, 'De geest van Crystal Palace', in: H.W. Lintsen et al. (Eds.), Geschiedenis van de techniek in Nederland: De wording van een moderne samenleving 1800-1890 (Zutphen 1993), deel VI, 13-16. 
was above all England that could now demonstrate to the world that it was the planet's leading nation.

The spirit of the Crystal Palace also haunted the Netherlands. The country adopted the culture that accompanied the belief in progress. Two rather modest expositions in 1847 and 1849 were followed by a whole series of national and regional expositions. In part they exhibited a broad selection of technological and industrial novelties. Sometimes they were also thematically oriented to, for example, agricultural machines, gas engines, or colonial products. The Palace for Popular Diligence [Paleis voor Volksvlijt] an imposing exposition hall built in 1864 in Amsterdam, became the Dutch ode to progress. The expositions also stimulated a culture of congresses. All kinds of organisations seized the opportunity to meet foreign colleagues and launch new initiatives. A Dutch journalist wrote in response to the founding of the International Workers Association during the World Exposition of 1862: 'We not only expect that its civilised culture will penetrate into all corners of the world, but also that this will give rise to useful cosmopolitan institutions, that must improve the material and moral condition of the European countries...' 14

The new culture also included a variety of periodicals that kept professionals and the public at large informed about developments in the Netherlands and especially in foreign countries. ${ }^{15}$ The general public was served by magazines like the Practical Peoples' Almanac (1854), Treasure of Health (1858), Contemporary Questions (1875) and Nature (1881). A professional readership had its own periodicals. Transactions of the Royal Society of Engineers (1848) were aimed at engineers and other technical experts. The Economist (1851) aimed to reach all those interested in domestic and foreign economics. The Observer (1866) was directed to 'architects, engineers, manufacturers, contractors and foremen.' Gas (1881) was the periodical of the directors of gasworks. The trade journals were the expression of the emergence of a professional mid-field that had begun to organize itself around academic curricula and professional associations.

The modernisation of the Dutch economy that took place in the second half of the nineteenth century, was not only the result of the liberalisation of trade, free enterprise and other economic variables, but most certainly also of a culture that viewed technical innovations almost by definition as social progress. ${ }^{16}$ But technology and science promised more than merely modernisation and economic development. ${ }^{17}$ In the course of centuries they had professed their ability to abolish poverty, end hunger and bring welfare for the masses.

\footnotetext{
${ }^{14}$ J.W. del Campo a.k.a. Camp, Verslag der Wereldtentoonstelling te Londen in 1862 ('s Gravenhage 1864), 436. Cited in: Bakker, 'De geest van Crystal Palace', 19.

${ }^{15}$ Van der Woud, Een nieuwe wereld, 16.

${ }^{16}$ See also: D. van Lente, Techniek en ideologie: Opvattingen over de maatschappelijke betekenis van technische vernieuwingen in Nederland, 1850-1920 (Groningen 1988). The minimal resistance to technology in Dutch politics and society is striking.

${ }^{17}$ See, among others: H.W. Lintsen, Made in Holland: Een techniekgeschiedenis van Nederland [1800-2000] (Zutphen 2005), 15-17.
} 
Was this a reasonable claim? Using the monitor for well-being we first explore the changes in quality of life for the period 1850-1910. We then change our focus to the natural capital that is viewed as the basis for well-being in this study. We make an inventory of several important shifts in the production of raw materials for the period 1850-1910 and of the derivative material flows. The overview provides the main themes that will be worked out in the rest of this book section.

\subsection{Well-being 'Here and Now': Less Extreme Poverty, 1850 Versus 1910}

The Dutch population nearly doubled between 1850 and 1910, increasing from 3.1 million to 5,9 million inhabitants. It may be considered a remarkable achievement that despite this growth well-being also increased (Table 7.1). In 1910, on average, every Netherlander had twice as much to spend as in 1850. Nevertheless it was not the case that extreme poverty - at the time the most important issue in well-being had disappeared. It is estimated that about $6 \%$ of the Netherlanders still lived in bitter poverty. As a percentage this represented a significant decline relative to 1850 (21\%). In absolute terms it still included about 350,000 fellow countrymen. Extreme poverty must have remained quite visible on the streets.

The decline of extreme poverty did not - as far as we can tell - occur gradually. Graph 7.1 uses estimates to chart the trend between 1850 and 1913. In the midnineteenth century poverty had increased again after a period of decline, in consequence of among other things the crisis of the colonial complex, the potato crisis, failed harvests and foreign wars (Chap. 3). But after these crises poverty continued to increase. The tide turned only in the 1860 s after which extreme poverty continued to decline until 1890. The initial increase after the crises and the subsequent decline demand an explanation. As we noted earlier, two factors played an important role in extreme poverty: economic growth and income inequality. Economic growth creates an increase in consumptive expenditures and less inequality a more equitable distribution of the latter among the population. Both factors will demand our attention in the following chapters.

On the basis of various indicators we can conclude that with increasing economic welfare the situation of the Dutch in the areas of health, nutrition, hygiene and education also improved. In one respect the personal situation had worsened, namely housing. At the outset of the twentieth century, many Netherlanders - estimates suggest some $60 \%$ - lived under poor conditions and occupied dwellings that by today's standards were too small. After 1850, public housing would become a prominent item in the debate on well-being.

From today's perspective the indicators for 1850 exhibit a negative trend relative to those for 1910 in regard to the natural environment and natural capital: a lower value for MSA (the indicator of biodiversity), higher values for $\mathrm{SO}_{2}$ and greenhouse gas emissions (the indicators for air quality) and a higher consumption of energy 
Table 7.1 Dashboard well-being 'here and now', 1850 versus 1910

\begin{tabular}{|c|c|c|c|c|c|}
\hline Theme & Indicator & Unit & \pm 1850 & \pm 1910 & \begin{tabular}{|l|} 
Corresponding \\
CBS methods
\end{tabular} \\
\hline Population & Size & million inhabitants & 3.1 & 5.9 & \\
\hline \multicolumn{6}{|c|}{ Material welfare and well-being } \\
\hline \multirow[t]{3}{*}{$\begin{array}{l}\text { Consumption, } \\
\text { income }\end{array}$} & $\begin{array}{l}\text { Consumptive expenditures } \\
\text { per capita/constant prices }\end{array}$ & index $(1850=100)$ & 100 & 200 & 今 \\
\hline & General income inequality & Gini coefficient $0-1$ & 0.48 & 0.47 & $\Longleftrightarrow$ \\
\hline & \begin{tabular}{|l|}
$\begin{array}{l}\text { Gendered income } \\
\text { inequality }\end{array}$ \\
\end{tabular} & $\begin{array}{l}\% \text { difference in hourly } \\
\text { wages } \mathrm{M} / \mathrm{W}\end{array}$ & $?$ & $?$ & $?$ \\
\hline $\begin{array}{l}\text { Subjective } \\
\text { well-being }\end{array}$ & Satisfaction with life & score $0-10$ & ? & $?$ & $?$ \\
\hline \multicolumn{6}{|c|}{ Personal characteristics } \\
\hline Health & Life expectancy & years & 37 & 55 & $\widehat{\mathrm{S}}$ \\
\hline Nutrition & Height & $\mathrm{cm}$ & 165 & 173 & 仓 \\
\hline \multirow[t]{2}{*}{ Housing } & Housing quality & $\%$ slums & 30 á 50 & 60 & 7 \\
\hline & Public water supply & $\mathrm{m}^{3} /$ capita & 0 & 19 & ૫ \\
\hline Physical safety & Murder victims & $\begin{array}{l}\text { number per } 100.000 \\
\text { inhabitants }\end{array}$ & 0.8 & 0.4 & ৬ \\
\hline Labour & Unemployment & $\%$ workforce & 6.4 & 2.0 & $\widehat{\triangleleft}$ \\
\hline Education & Educational level & years & 3 & 5.8 & $\widehat{\sqcup}$ \\
\hline Free time & Free time & hours / week & $?$ & $?$ & \\
\hline \multicolumn{6}{|c|}{ Natural environment } \\
\hline Biodiversity & MSA & $\%$ original biodiversity & 73 & 54 & 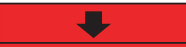 \\
\hline \multirow[t]{2}{*}{ Air quality } & $\mathrm{SO}_{2}$ & $\mathrm{~kg} \mathrm{SO}_{2} /$ capita & 1.3 & 4.6 & 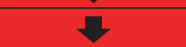 \\
\hline & Greenhouse gas emissions & ton $\mathrm{CO}_{2} /$ capita & 1.2 & 3.8 & t \\
\hline Water quality & Public water supply & $\mathrm{m}^{3} /$ capita & 0 & 19 & $\widehat{\Delta}$ \\
\hline \multicolumn{6}{|c|}{ Institutional context } \\
\hline Trust & Generalised trust & $\begin{array}{l}\text { \% population with } \\
\text { adequate trust }\end{array}$ & $?$ & $?$ & $?$ \\
\hline $\begin{array}{l}\text { Political } \\
\text { institutions }\end{array}$ & Democracy & democracy-index 0-100 & 0.3 & 9.5 & ৬ \\
\hline
\end{tabular}

Legend

\begin{tabular}{|c|l|}
\hline$仓$ & Positive development \\
\hline \multirow{2}{\longleftrightarrow}{} & Negative development \\
\hline \multirow{2}{*}{} & Not positive/not negative \\
\hline
\end{tabular}

Source: See note 23 of Chap. 2 
Graph 7.1 Percentage of the population living under the line of extreme poverty, 1850-1913

Source: Appendix 4.1

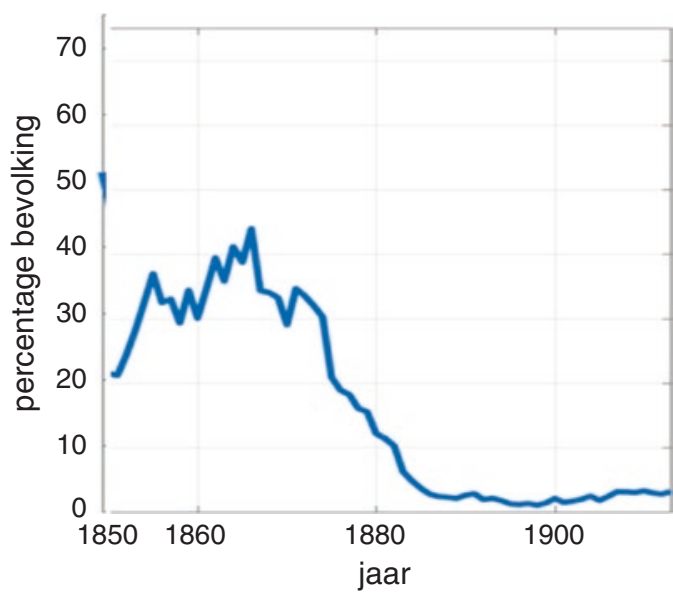

and raw materials (the indicators for the exploitation of natural capital) (Tables 7.1 and 7.2). The monitor here shows that trade-offs are inherent to changes in wellbeing. The increase in well-being here was based on more forceful exploitation of natural capital. In 1913 the Netherlands had access to almost four times more raw materials than in 1850, partly from domestic and partly from foreign sources. This enabled the Dutch to feed themselves better, to produce more, to clothe themselves better, to increase trade, achieve better water management etc. This was accompanied by a decrease in biodiversity and in air quality. The question is to what extent this is problematic. How must the 'gains' and 'losses' be weighed according to present-day norms? But the contemporary perspective is also of importance: what did contemporaries think of the trade-offs that took place? These questions guide the research informing this book section.

\subsection{Well-being 'Later': An Economy Under Steam, 1850 Versus 1910}

The quality of life for future generations depends on the resources left them by preceding generations. Resources are included in the monitor under four types of capital: natural, economic, human and social capitals. Natural capital has a special position. Its exploitation with the aid of the other three capitals is the basis for a given quality of life. Natural capital has already been briefly discussed. The other three capitals - as the monitor shows - are in much better shape in 1910 than they were in 1850 .

The stock of economic capital per Netherlander was twice as high in 1910 as it was in 1850, the national debt had shrunk by more than half and measures had been taken to get a modern knowledge infrastructure off the ground. The monitor uses investments in research and development $(R \& D)$ as an indicator for the supply of 
Table 7.2 Dashboard well-being 'later', 1850 versus 1910

\begin{tabular}{|c|c|c|c|c|c|}
\hline Theme & Indicator & Unit & $\pm \mathbf{1 8 5 0}$ & \pm 1910 & $\begin{array}{l}\text { Corresponding } \\
\text { CBS methods }\end{array}$ \\
\hline \multicolumn{6}{|l|}{ Natural Capital } \\
\hline Energy & Energy consumption & TJ/capita & 0.03 & 0.05 & 5 \\
\hline $\begin{array}{l}\text { Non-fossil } \\
\text { resources }\end{array}$ & $\begin{array}{l}\text { Gross domestic } \\
\text { consumption }\end{array}$ & ton/capita & 2.1 & 3.8 & 8 \\
\hline Biodiversity & MSA & $\%$ original biodiversity & 73 & 54 & 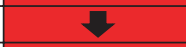 \\
\hline \multirow[t]{2}{*}{ Air quality } & $\mathrm{SO}_{2}$ emissions & $\mathrm{kg} \mathrm{SO}_{2} /$ capita & 1.2 & 3.8 & 7 \\
\hline & Greenhouse gas emissions & ton $\mathrm{CO}_{2}$ /capita & 0 & 19 & V \\
\hline Water quality & Public water supply & $\mathrm{m}^{3 / \text { capita }}$ & 1.3 & 4.6 & $\widehat{\mathrm{s}}$ \\
\hline \multicolumn{6}{|c|}{ Economic capital: } \\
\hline Physical capital & $\begin{array}{l}\text { Economic capital } \\
\text { stock/capita }\end{array}$ & index $(1850=100)$ & 100 & 141 & $\widehat{\mathrm{S}}$ \\
\hline $\begin{array}{l}\text { Financial } \\
\text { capital }\end{array}$ & Gross national debt & $\%$ gdp & 194 & 71 & $\widehat{\mathrm{S}}$ \\
\hline Knowledge & Stock knowledge capital & index $(2010=100)$ & - & $<0.5$ & $\widehat{\mathrm{S}}$ \\
\hline \multicolumn{6}{|c|}{ Human capital: } \\
\hline Health & Life expectancy & years & 37 & 55 & $\widehat{\mathrm{S}}$ \\
\hline Labour & Unemployment & $\%$ workforce & 6.4 & 2.0 & ऽ \\
\hline $\begin{array}{l}\text { Level of } \\
\text { education }\end{array}$ & Schooling & years & 3 & 5.8 & $\widehat{\mathrm{v}}$ \\
\hline \multicolumn{6}{|l|}{ Social Capital: } \\
\hline Trust & Generalised trust & $\begin{array}{l}\% \text { population with } \\
\text { adequate trust }\end{array}$ & ? & ? & ૫ \\
\hline \begin{tabular}{|l|} 
Political \\
institutions
\end{tabular} & Democracy & democracy index $0-100$ & 0.3 & 9.5 & 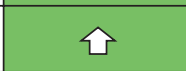 \\
\hline
\end{tabular}

\section{Legend}

\begin{tabular}{|c|c|}
\hline ૫ & Positive development \\
\hline$\sqrt{1}$ & Negative development \\
\hline$\Longleftrightarrow$ & Not positive/not negative \\
\hline ? & Unknown or irrelevant \\
\hline
\end{tabular}

Source: See note 23 of Chap. 2

modern knowledge capital. Its extent is unknown. However, in 1850 there were hardly any private or semi-governmental laboratories; around 1910 at least 40 could be counted. ${ }^{18}$ According to the monitor, the volume of human capital had also increased in 1910 relative to 1850 .

The condition of the Dutch population had improved, educational levels had increased and there was a surfeit of work. In terms of political participation, social capital was more robust in 1910 than in 1850. Trust in political institutions will have to be estimated qualitatively. In our estimation this was not particularly high in

\footnotetext{
${ }^{18} \mathrm{~J}$. Hutter, 'Nederlandse laboratoria 1860-1940, een kwantitatief overzicht', Tijdschrift voor de Geschiedenis der Geneeskunde, Natuurwetenschappen, Wiskunde en Techniek 9(1986), nr.54, 150-174, graph 1.
} 
1850 , but around the turn of the century there was also much political turbulence, as we shall see.

The question here is to what extent investments in the three capitals by successive generations between 1850 and 1910 led to an improvement in the quality of life of each generation itself and to a better point of departure for the next generation. Around 1850 the Netherlands still had, in various respects, a classical economy dominated by agriculture, craft production and by trade in colonial and domestic products. A central question of this section is: How did the modernisation of the economy and the indices of well-being develop in successive decades?

\subsection{Well-being 'Elsewhere': Colonial Profit, 1850 Versus 1910}

What claims did the Netherlands stake to natural capital elsewhere in the world? To answer this question, the monitor provides only one usable indicator for this period, namely imports of raw materials. This indicator, however, reveals much. In 1913 the Netherlands imported 8 á 9 times more raw materials per capita than in 1850. Of all the raw materials (in kilotons) that were at the disposal of the Netherlands at the beginning of the twentieth century, about half was imported! In 1850 that was only 13\%. ${ }^{19}$ The Netherlands had become considerably more dependent on foreign raw materials, especially stone (100\%, primarily limestone to make cement), coal $(88 \%)$, gravel 67\%) and grain (68\%) (Table 7.5). The same dependency held for a series of industrial products like metal products $(86 \%)$, artificial fertiliser $(81 \%)$, cokes $(64 \%)$ and wooden planks (61\%). Dependence made the Netherlands vulnerable. Did that worry contemporaries? That was one side of the coin. The other side was the influence of these imports on well-being elsewhere.

In this connection the relationship to the colonies once again demands our attention. Above we noted the dependence of the state finances around 1850 on the colonial credit balance. We also pointed out the effects on the lives of the Javanese population. In the same period the Cultivation System came under increasingly heavy fire. In 1860 the writer Multatuli (pseudonym for Eduard Douwes Dekker) would publish the Max Havelaar, an indictment of the Cultivation System, forced labour and the corrupt government in the Dutch East Indies. To what extent did this kind of opposition lead to reforms? (Table 7.3)

\footnotetext{
${ }^{19}$ The total weight of available raw materials in 1850 (bio, mineral and fossil) was $9700 \mathrm{kton}$, of which 1300 kton was imported. For 1913 these figures were respectively 40.000 kton and 20.400 kton (see appendix 2.1).
} 
Table 7.3 Dashboard well-being 'elsewhere' 1850 versus 1910

\begin{tabular}{|l|l|l|l|c|c|}
\hline Theme & Indicator & $\pm \mathbf{1 8 5 0}$ & $\pm \mathbf{1 9 1 0}$ & $\begin{array}{l}\text { Corresponding } \\
\text { CBS methods }\end{array}$ \\
\hline Material Welfare & $\%$ gdp & - & - & $?$ \\
\hline $\begin{array}{l}\text { Consumption, } \\
\text { income }\end{array}$ & Development aid & & \\
\hline Natural capital & \multicolumn{1}{|l|}{0.4} & 3.4 & $?$ \\
\hline Natural capital & Import of raw materials & ton/capita & \\
\hline
\end{tabular}

\section{Legend}

\begin{tabular}{|c|c|}
\hline 仓 & Positive development \\
\hline 5 & Negative development \\
\hline$\Leftrightarrow$ & Not positive/not negative \\
\hline ? & Unknown or irrelevant \\
\hline
\end{tabular}

Source: See note 23 of Chap. 2

\subsection{Natural Capital and Material Flows, 1850 Versus 1910}

Natural capital is the basis of the quality of life, that is the presupposition of this study. Three varieties of natural capital can be distinguished: bio-raw materials, mineral subsoil resources and fossil subsoil resources. These are the origin of three material flows, that can be roughly denoted as agriculture and foods, construction and building materials and energy. Along these lines, the link with the most important problems of quality of life in the second half of the nineteenth century can be directly laid. The material flow 'agriculture and foods' was decisive for the food situation of the Dutch population: famine, malnutrition, food quality, food distribution and food security. The material flow 'construction and building materials' was decisive for public health (the construction of public hygienic facilities), public housing (the construction of dwellings for the poor and workers) and the maintenance of a safe delta (the struggle against the sea, inner water and the rivers). The material flow 'energy' was decisive for providing heat to the households of the poor and workers in preparing meals and fighting the cold. In addition, the same time the three material flows were part of an economic system that generated surplus value and economic growth that enabled the achievement of a higher level of well-being, in particular for the poor and the workers. At the same time natural capital is part of a process of trade-offs. From a present-day perspective, more intensive exploitation means increasing depletion of natural resources.

What changes did natural capital and the material flows in the period 1850-1910 undergo? We can identify four. First of all, we noted above that at the outset of the twentieth century the Netherlands commanded significantly more raw materials than in 1850 , about four times as much. This came down to twice as much per capita 
Table 7.4 Raw materials in the Netherlands, 1850 versus 1913 in kilotons

\begin{tabular}{|c|c|c|c|}
\hline & 1850 & 1913 & Ratio 1850:1913 \\
\hline \multicolumn{4}{|l|}{ Bio raw materials: } \\
\hline Gross available & 5260 kton & 14,740 kton & $1: 2.8$ \\
\hline Bio/capita & 1.7 ton/capita & 2.4 ton/capita & $1: 1.4$ \\
\hline$\%$ import & $11 \%$ & $22 \%$ & $1: 2.0$ \\
\hline$\%$ export & $6 \%$ & $14 \%$ & $1: 2.3$ \\
\hline \multicolumn{4}{|c|}{ Mineral subsoil resources: } \\
\hline Gross available & 1350 kton & 8040 kton & $1: 6.0$ \\
\hline Mineral/capita & 0.45 ton/capita & 1.3 ton/capita & $1: 2.9$ \\
\hline$\%$ import & $11 \%$ & $33 \%$ & $1: 3.0$ \\
\hline$\%$ export & $2 \%$ & $8 \%$ & $1: 4.0$ \\
\hline \multicolumn{4}{|l|}{ Fossil subsoil resources: } \\
\hline Gross available & 3060 kton & 17,430 kton & $1: 5.7$ \\
\hline Fossil/capita & 1.0 ton/capita & 2.8 ton/capita & $1: 2.8$ \\
\hline$\%$ import & $18 \%$ & $81 \%$ & $1: 4.5$ \\
\hline$\%$ export & $1 \%$ & $32 \%$ & $1: 32$ \\
\hline \multicolumn{4}{|l|}{ Total raw materials: } \\
\hline Gross available & 9670 kton & 40,210 kton & $1: 4.2$ \\
\hline Raw materials/capita & 3.1 ton/capita & 6.5 ton/capita & $1: 2.1$ \\
\hline$\%$ import & $13 \%$ & $50 \%$ & $1: 3.8$ \\
\hline$\%$ export & $4 \%$ & $21 \%$ & $1: 5.3$ \\
\hline
\end{tabular}

Remark: Gross available $=$ domestic production + imports

Source: F. Lambert, Massastromen in Nederland. In de jaren 1850, 1913, 1970, 2010 (researchrapport Technische Universiteit Eindhoven, oktober 2016).

(Table 7.4). Mineral and fossil subsoil resources in particular were much more intensively exploited, their use increasing by a factor of five or six. In the second place, the Netherlands were ever more tightly integrated into an international economy. Imports of raw materials increased by nearly $400 \%$ and exports by a factor of five. Imports of processed goods also increased substantially (Tables 7.4 and 7.7). In the third place, industrial processing of raw materials more and more became the norm: In $185026 \%$ of the bio-raw materials were industrially processed as opposed to $51 \%$ in 1913 ; for mineral raw materials the figures were respectively $54 \%$ against $60 \%$. Finally, in terms of volume, entirely different raw materials and products dominated the Dutch economy in 1913 in comparison with 1850 (Tables 7.5 and 7.8).

This last shift illustrates the modernisation of the economy that took place in this period. Coal replaced turf as the most important fossil subsoil resource. Metal products and machinery had joined the top-ten list of manufactured goods. Both developments thus represented the mechanisation of production. Gravel and stone (marl) had conquered a place among the top ten raw materials and concrete products filled a slot in the top ten processed goods. This reflects the rise of concrete technology 
Table 7.5 Ten most prominent raw materials (in kton) and the percentage imported, 1850 versus 1913

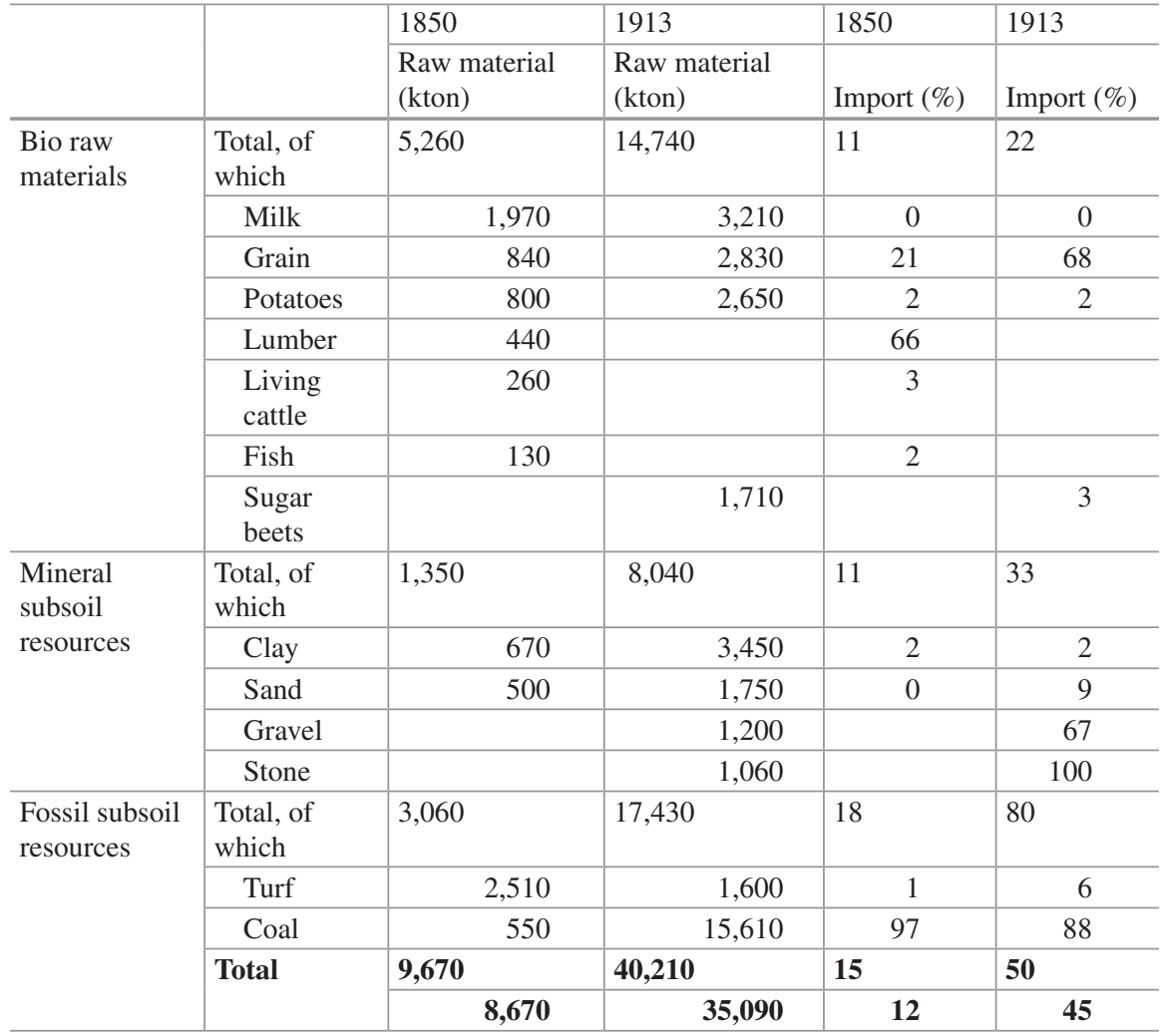

Source: F. Lambert, Massastromen in Nederland. In de jaren 1850, 1913, 1970, 2010 (researchrapport Technische Universiteit Eindhoven, oktober 2016)

and of concrete as new building material. As far as agriculture and foods are concerned, various raw materials (like cattle and fish) and processed products (like beverages and meat) disappeared from the top ten. They were replaced only by sugar beets. This is illustrative of the slow but certain decline of the relative importance of agriculture and foods in the Dutch economy. To be sure, this sector also modernised, as illustrated by the arrival of artificial fertiliser and sugar beets (in support of a new industry, the beetroot sugar industry) in the top ten.

In 1850 the Netherlands faced a major challenge. As the monitor 1850-1910 shows, much remained to be done in the area of well-being. Extreme poverty was widespread and had become the most important issue of well-being in all of Dutch history. The satisfaction of primary needs exhibited serious shortcomings. At the same time the population continued to grow and to dwell in an unsafe delta. 
The Netherlands sought a solution for these issues in a new mode of exploitation of natural capital, 'here' in the Netherlands and 'elsewhere.' Changes in material flows point to this. The question is to what extent this brought new problems to the fore. The monitor suggests these might be found in the domain of the natural environment and natural capital. The question in this context is then: in what way are the dynamics of the material flows related to changes in well-being and sustainability. In this analysis we take bio-materials (agriculture and foods), mineral materials (construction and building materials) and fossil materials (energy) as our point of departure (Tables 7.6, 7.7 and 7.8).

Table 7.6 Percentage of raw materials and subsoil resources industrially processed, 1850 versus 1913

\begin{tabular}{l|l|l}
\hline & 1850 & 1913 \\
\cline { 2 - 3 } & $\begin{array}{l}\text { Industrial processing of raw } \\
\text { materials and subsoil resources }\end{array}$ & $\begin{array}{l}\text { Industrial processing of raw } \\
\text { materials and subsoil resources }\end{array}$ \\
\hline Bio-raw materials & $20 \%$ & $51 \%$ \\
\hline $\begin{array}{l}\text { Mineral subsoil } \\
\text { resources }\end{array}$ & $54 \%$ & $60 \%$ \\
\hline $\begin{array}{l}\text { Fossil subsoil } \\
\text { resources }\end{array}$ & $0 \%$ & $7 \%$ \\
\hline
\end{tabular}

Remark 1: 'Industry' excludes extraction of mineral and fossil subsoil resources

Remark 2: Mineral resources such as clay and sand directly used in building activities (in for example dikes) are not treated as processed materials

Source: F. Lambert, Massastromen in Nederland. In de jaren 1850, 1913, 1970, 2010 (researchrapport Technische Universiteit Eindhoven, oktober 2016)

Table 7.7 Import and export of processed products in kton and percentages, 1850 versus 1913

\begin{tabular}{l|l|l}
\hline & 1850 & 1913 \\
\hline Total import & $1480 \mathrm{kton}$ & $26,000 \mathrm{kton}$ \\
\hline Import processed products & $190 \mathrm{kton}$ & $6060 \mathrm{kton}$ \\
\hline Import processed products $\%$ of total) & $13 \%$ & $23 \%$ \\
\hline Total export & $570 \mathrm{kton}$ & $11,420 \mathrm{kton}$ \\
\hline Export processed products & $170 \mathrm{kton}$ & $3110 \mathrm{kton}$ \\
\hline Export processed products (\% of total) & $30 \%$ & $27 \%$ \\
\hline
\end{tabular}

Source: F. Lambert, Massastromen in Nederland. In de jaren 1850, 1913, 1970, 2010 (researchrapport Technische Universiteit Eindhoven, oktober 2016) 
Table 7.8 Ten most prominent processed products (in kilotons) and the percentages imported and exported, 1850 versus 1913

\begin{tabular}{|c|c|c|c|c|c|c|c|}
\hline & & 1850 & 1913 & 1850 & 1913 & 1850 & 1913 \\
\hline & & $\begin{array}{l}\text { Processed } \\
\text { products } \\
\text { (kton) }\end{array}$ & $\begin{array}{l}\text { Processed } \\
\text { products } \\
(\mathrm{kton})\end{array}$ & $\begin{array}{l}\text { Import } \\
(\%)\end{array}$ & $\begin{array}{l}\text { Import } \\
(\%)\end{array}$ & $\begin{array}{l}\text { Export } \\
(\%)\end{array}$ & $\begin{array}{l}\text { Export } \\
(\%)\end{array}$ \\
\hline Food & Bread & 320 & 860 & 0 & 0 & 0 & 0 \\
\hline processing & Flour & 220 & 750 & 0 & 30 & 0 & 10 \\
\hline & Beverages & 170 & & 5 & & 7 & \\
\hline & Meat & 110 & & 2 & & 4 & \\
\hline & Grain chaff & 100 & & 0 & & 0 & \\
\hline & Sugar & 80 & & 100 & & 75 & \\
\hline & Fodder grain & & 1260 & & 8 & & 13 \\
\hline $\begin{array}{l}\text { Lumber } \\
\text { industry }\end{array}$ & $\begin{array}{l}\text { Wood } \\
\text { processing }\end{array}$ & 210 & 1450 & 6 & 61 & 1 & 0 \\
\hline & Wood waste & 150 & & 0 & & 0 & \\
\hline $\begin{array}{l}\text { Mineral } \\
\text { processing } \\
\text { industry }\end{array}$ & $\begin{array}{l}\text { Coarse } \\
\text { ceramics (e.g. } \\
\text { bricks) }\end{array}$ & 670 & 3100 & 2 & 10 & 5 & 0 \\
\hline & Chalk & 70 & & 5 & & 4 & \\
\hline & $\begin{array}{l}\text { Concrete } \\
\text { products }\end{array}$ & & 580 & & 0 & & 0 \\
\hline Chemical & Cokes & & 1330 & & 64 & & 50 \\
\hline industry & $\begin{array}{l}\text { Artificial } \\
\text { fertiliser }\end{array}$ & & 880 & & 81 & & 30 \\
\hline $\begin{array}{l}\text { Metals and } \\
\text { machine }\end{array}$ & $\begin{array}{l}\text { Metal } \\
\text { products }\end{array}$ & & 950 & & 86 & & 4 \\
\hline industry & $\begin{array}{l}\text { Machine } \\
\text { building }\end{array}$ & & 610 & & 20 & & 6 \\
\hline
\end{tabular}

Source: F. Lambert, Massastromen in Nederland. In de jaren 1850, 1913, 1970, 2010 (researchrapport Technische Universiteit Eindhoven, oktober 2016)

\section{Literature}

Bakker, M. (1995). 'De geest van Crystal Palace'. In H.W. Lintsen et al. (Eds.), Geschiedenis van de techniek in Nederland: De wording van een moderne samenleving 1800-1890 (Vol. VI, pp. 13-26). Zutphen: Walburg.

Berkers, E. (2002). Technocraten en bureaucraten: Ontwikkeling van organisatie en personeel van de Rijkswaterstaat, 1848-1930. Zaltbommel: Europese Bibliotheek.

Hutter, J. (1986). 'Nederlandse laboratoria, 1860-1940: Een kwantitatief overzicht'. Tijdschrift voor de Geschiedenis der Geneeskunde, Natuurwetenschappen, Wiskunde en Techniek, 9(54), $150-174$.

Koch, J. (2013). Koning Willem I, 1772-1843. Amsterdam: Bert Bakker.

Lente, D. van (1998). Techniek en ideologie: Opvattingen over de maatschappelijke betekenis van technische vernieuwingen in Nederland, 1850-1920. Groningen: Wolters.

Lintsen, H.W., R.A. Lombaerts and R. Moerenhout (1994). 'De droogmaking van het Haarlemmermeer: Wind of stoom'. In M.L. ten Horn-van Nispen, H.W. Lintsen and 
A.J. Veenendaal (Eds.), Nederlandse ingenieurs en hun kunstwerken: Tweehonderd jaar civiele techniek (pp. 31-40). Zutphen: Walburg Pers.

Lintsen, H.W. (2005). Made in Holland: Een techniekgeschiedenis van Nederland [1800-2000]. Zutphen: Walburg Pers.

Mom, G. and R. Filarski (2008). Van transport naar mobiliteit: De mobiliteitsexplosie (18952005). Zutphen: Walburg Pers.

Robijns, M.J.F. (1988). 'Meter, Eillert'. Biografisch Woordenboek van het Socialisme en de Arbeidersbeweging in Nederland, 3, 132-135.

Rooy, P. de (2014). Ons stipje op de waereldkaart: De politieke cultuur van modern Nederland. Amsterdam: Wereldbibliotheek.

Woud, A. van der (2006). Een nieuwe wereld: Het ontstaan van het moderne Nederland. Amsterdam: Bert Bakker.

Zanden, J.L. van and A. van Riel (2000). Nederland 1780-1914: Staat, instituties en economische ontwikkeling. Amsterdam: Balans.

Open Access This chapter is licensed under the terms of the Creative Commons Attribution 4.0 International License (http://creativecommons.org/licenses/by/4.0/), which permits use, sharing, adaptation, distribution and reproduction in any medium or format, as long as you give appropriate credit to the original author(s) and the source, provide a link to the Creative Commons license and indicate if changes were made.

The images or other third party material in this chapter are included in the chapter's Creative Commons license, unless indicated otherwise in a credit line to the material. If material is not included in the chapter's Creative Commons license and your intended use is not permitted by statutory regulation or exceeds the permitted use, you will need to obtain permission directly from the copyright holder.

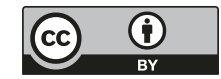

